\title{
Sheep Losses to Predators on a California Range, $1973-1983$
}

\author{
JERRY H. SCRIVNER, WALTER E. HOWARD, ALFRED H. MURPHY, AND JOHN R. HAYS
}

\begin{abstract}
Predation at the University of California Hopland Field Station was evaluated for an 11-year period beginning in 1973. Of those lambs placed on range, an average of $2.7 \%$ were killed each year by predators. An average of $1.5 \%$ of the ewes were killed. When the number of missing animals which were killed was estimated, the average annual predation rate for lambs and ewes killed was 10.4 and $3.8 \%$, respectively. For all known ewe and lamb deaths, respectively, $45 \%$ and $26 \%$ were caused by predators, $14 \%$ and $28 \%$ died from causes other than predation, and $41 \%$ and $46 \%$ died from unknown causes. Of those sheep killed by predators, $89 \%$ were killed by coyotes (Canis latrans), $8 \%$ by dogs. and $1 \%$ each by black bear (Ursus americanus), mountain lion (Felis concolor), and golden eagle (Aquila chrysaetos). More sheep were killed by coyotes from October to March than from April to September and the annual number of sheep killed by coyotes and dogs has increased since the beginning of the study. Not including the value of missing animals which were killed, the present value of livestock killed by predators was estimated to be $\$ 62,364$.

Numerous studies have documented sheep losses to predators (see U.S. Fish and Wildlife Service 1978). Most studies discuss

The authors are postdoctoral researcher and professor. Division of Wildlife and Fisheries Biology, University of California. Davis 95616; and superintendent and animal resource supervisor, University of California Hopland Field Station, 4070 University Road. Hopland, California 95449.

The authors thank D.M. Center. R.M. Dally, and C.E. Vaughn for reviewing the manuscript.

Manuscript accepted November 20, 1984.
\end{abstract}

livestock losses occurring during a few years. While short-term studies provide useful information, conclusions based on such research must be made with caution because factors such as predator density, environmental conditions, and availability of alternate prey vary annually and may influence predation.

Generally, conclusions regarding livestock losses to predators are more reliable when long-term data are used; however, such data are rare. The purpose of this study was to evaluate livestock and economic losses to predators for a 11 -year period beginning in 1973 for a sheep operation in the northern coastal area of California.

\section{Study Area and Methods}

Data for the study were gathered at the University of California Hopland Field Station. The station was established in 1951 to provide a location where data could be gathered on how rangeland should be managed to increase production of feed for livestock and the importance of rangeland to wildlife, for recreation, and as watershed. Murphy and Heady (1983) provide.a detailed description of the area.

The station is comprised of 2,168 ha ranging in elevation from about 150 to $915 \mathrm{~m}$. There are 32 sheep-fenced pastures totaling 1,870 ha, 12 deer-proof fenced pastures totaling about 100 ha, 3 livestock-free areas (established in 1957) totaling 190 ha, and 8 ha of irrigated pastures. 


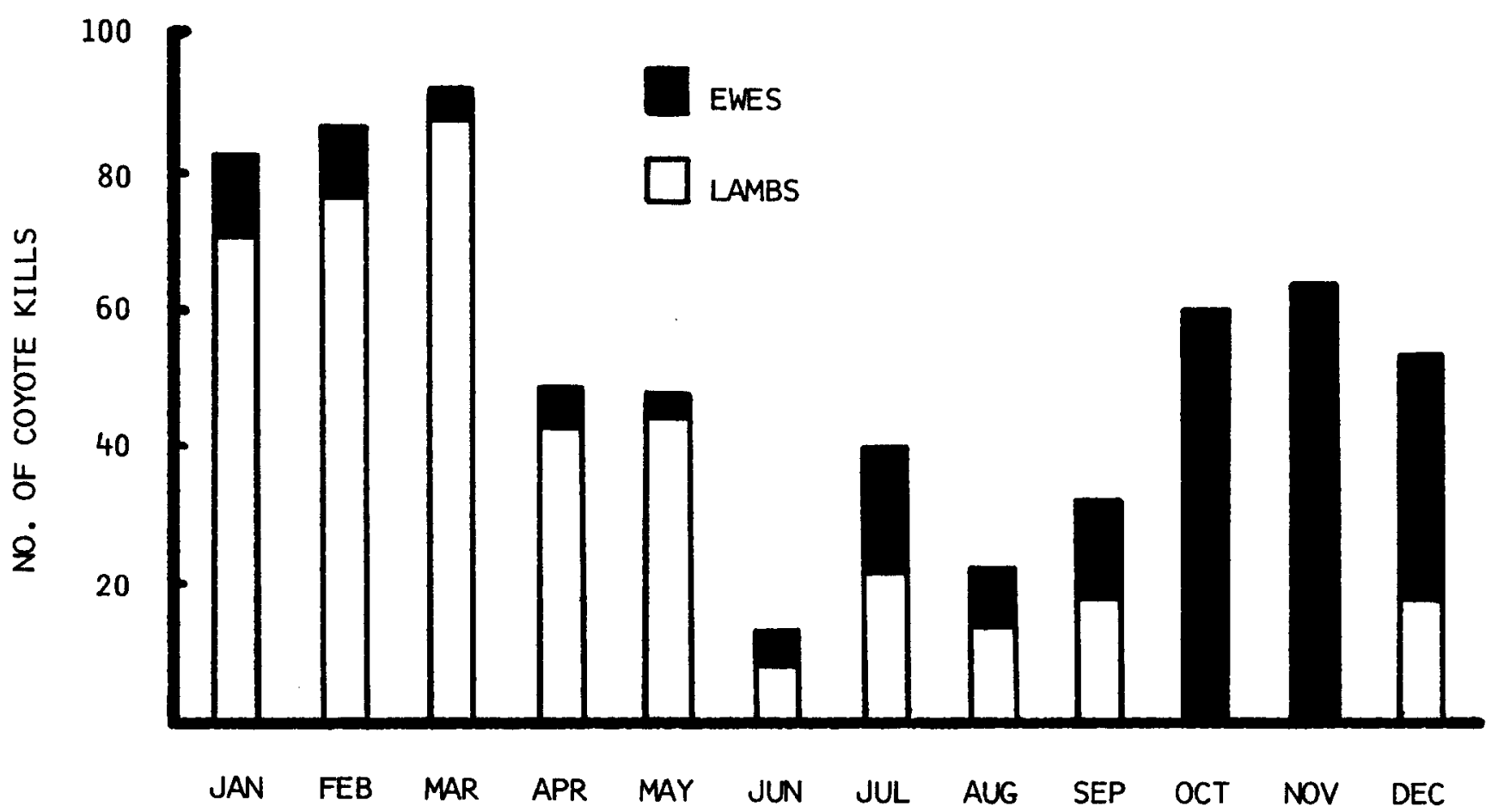

Fig. 1. The total number of lambs and ewes known to have been killed by coyotes from 1973-1983 at the University of California Hopland Field Station.

The Field Station typically has mild, rainy winters and hot dry summers. Annual rainfall averages about $90 \mathrm{~cm} /$ year. Temperature averages approximately $21^{\circ} \mathrm{C}$ in the summer and $8^{\circ} \mathrm{C}$ in the winter. The vegetation is almost equally divided into 4 cover types: grass, woodland grass, dense woodland, and chaparral.

Some predation studies have been criticized because they rely on loss data provided by ranchers who allegedly exaggerate losses to predators (Armentrout 1980). In this study, sheep were managed by University employees and therefore losses attributed to predators were thought to be unbiased. Although the Field Station has kept livestock records since it was established, records pertaining to losses to predators were most reliable beginning in 1973 when a shepherd was employed who systematically recorded loss data. The same shepherd was responsible for gathering loss data throughout the study. The shepherd's daily journal, grazing records, and records of individual ewes and lambs were used as a source of data regarding animal deaths.

For each animal, the following data were compiled: (1) animal identification number, (2) date animal died, (3) cause of death, and (4) location of death. Losses were classified as: (1) those caused by predators, (2) those not caused by predators, (3) those found dead but for which the cause of death was unknown. Deaths caused by predators were established from tooth-puncture wounds. wounds in skin and bones, hemorrhage around tooth marks, and tracks at kill sites. Between year comparisons of sheep losses to predators were made using Spearman Rank Correlation (Gibbons 1976). The Spearman coefficient was considered statistically significant when $p<0.05$.

Table 1. Sheep losses to various causes at the University of California Hopland Field Station, $1973-1983$.

\begin{tabular}{|c|c|c|c|c|c|c|c|c|c|c|c|}
\hline & \multicolumn{3}{|c|}{$\begin{array}{c}\text { No. of lambs known } \\
\text { dead by causes }\end{array}$} & \multicolumn{3}{|c|}{$\begin{array}{l}\text { No. of ewes known } \\
\text { dead by causes }\end{array}$} & \multicolumn{5}{|c|}{ Causes of predation by species } \\
\hline & Predator & Other & Unknown & Predator & Other & Unknown & Coyote & Dog & Eagle & Lion & Bear \\
\hline 1983 & 28 & 14 & 53 & 20 & 26 & 37 & 32 & 10 & 0 & 0 & 6 \\
\hline 1982 & 70 & 3 & 76 & 11 & 12 & 43 & 76 & 4 & 1 & 0 & 0 \\
\hline 1981 . & 71 & 14 & 30 & 63 & 61 & 52 & 111 & 20 & 3 & 0 & 0 \\
\hline 1980 & 26 & 6 & 17 & 41 & 39 & 46 & 66 & 1 & 0 & 0 & 0 \\
\hline 1979 & 60 & 22 & 41 & 30 & 35 & 70 & 87 & 3 & 0 & 0 & 0 \\
\hline 1978 & 21 & 9 & 32 & 35 & 24 & 43 & 49 & 6 & 1 & 0 & 0 \\
\hline 1977 & 66 & 3 & 23 & 22 & 24 & 42 & 85 & 3 & 0 & 0 & 0 \\
\hline 1976 & 60 & 15 & 19 & 32 & 31 & 48 & 76 & 11 & 0 & 5 & 0 \\
\hline 1975 & 10 & 23 & 31 & 27 & 32 & 40 & 36 & 1 & 0 & 0 & 0 \\
\hline 1974 & 11 & 16 & 30 & 20 & 34 & 75 & 28 & 3 & 0 & 0 & 0 \\
\hline 1973 & 9 & 6 & 38 & 11 & 25 & 65 & 19 & 1 & 0 & 0 & 0 \\
\hline Total & 432 & 131 & 390 & 312 & 343 & 561 & 665 & 63 & 5 & 5 & 6 \\
\hline $\bar{x}$ & 39 & 12 & 35 & 28 & 31 & 51 & 60 & 6 & 0.5 & 0.5 & 0.6 \\
\hline SD & 26 & 7 & 17 & 15 & 12 & 13 & 29 & 6 & 0.9 & 1.5 & 1.8 \\
\hline
\end{tabular}

'Does not include lambs which died in barn.

Includes "yearlings" (78 predator kills, 20 other, and 32 unknown). 


\section{Results and Discussion}

\section{Livestock Losses}

During the 11-year period for which data were analyzed, the Field Station had an average of 1,425 (SD=131) mature ewes. Generally, sheep were managed as they would be on a private sheep operation. Breeding usually began in July. Lambing began in November but most lambs were born from late December to mid-January. Lambs were born in the barn and held in individual pens with ewes for 1 to 2 days prior to placement on range. An averagc of $1,422(S D=120)$ lambs were placed on range each year. Sheep were usually checked daily but were not accompanied by a herder.

Lambs were usually inventoried in March, weaned in May, and then either sold or retained as replacements. An average of 447 ( $S D=97)$ lambs were retained as replacements. Lambs werc classified as "yearlings" beginning in October. Of those lambs placed on range, an average of $2.7 \%(\mathrm{SD}=1.7 \%)$ were killed each year by predators. This percentage does not include lambs classified as yearlings and then killed. Based on the number of mature ewes present on the station July 1 of each year, an average of $1.5 \%$ $(\mathrm{SD}=1.0 \%)$ of the mature ewes were killed. After reviewing the literature regarding livestock losses to predators, the U.S. Fish and Wildlife (1978) concluded that in the western states, the average loss to coyotes was from 4 to $8 \%$ of the lambs and 1 to $2.5 \%$ of the ewes over the period 1972 to 1978 .

For all known lamb and ewe deaths, respectively, $45 \%$ and $26 \%$ were killed by predators, $14 \%$ and $28 \%$ died from causes other than predation, and $41 \%$ and $46 \%$ died from unknown causes (Table 1). Gee et al. (1977) estimated that for all known lamb and ewe deaths in California, $47 \%$ to the lambs and $33 \%$ of the ewes were killed by predators, $33 \%$ of the lambs and $52 \%$ of the ewes died from other known causes, and $19 \%$ of the lambs and $14 \%$ of the ewes died from unknown causes. Gee's data regarding lamb losses were based on the number of lambs born and not just those placed on range. Whereas the percentage of lamb and ewe deaths due to predators in the above study was similar to that found in this study, Gee et al. (1977) reported a grcatcr percentage of deaths due to known causes other than predation and a smaller percentage of deaths due to unknown causes.

The loss percentages in this study are underestimates because they do not include missing animals which were killed. Based on Field Station annual reports, a total of 1,651 ewes and 2,658 lambs were missing from 1973 to 1983 . Taylor et al. (1978) estimated the number of undiscovered predation kills by assuming that the carcasses found represented a random sample of the total number of sheep lost. The proportion of predator kills a mong those carcasses found, therefore, should be the same as among the undiscovered missing animals.

Applying the above logic, 1,196 of the missing lambs and 355 of the missing ewes may have been killed by predators. For lambs, this was estimated by multiplying the percentage of lambs known killed $(45 \%)$ by the number of missing la mbs $(2,658)$. The number of missing ewes which were killed was estimated by subtracting yearling losses to all causes (Table 1, footnote 2) from total ewe losses to determine the percentage of mature ewes killed (21.5\%) and then multiplying his percentage by the number of missing mature ewes $(1,651)$. Based on the number of lambs and ewes known and estimated to have been killed, an average of $10.4 \%$ of the lambs and $3.8 \%$ of the ewes were killed each year.

About $89 \%$ of the known predator kills were caused by coyotes Three-year running averages of sheep losses to coyotes were calculated to moderate annual fluctuations. Based on these running averages, there was a statistically significant increase in the number of coyote kills occurring at the Hopland Field Station since 1973 $(R=0.817)$. This increase has occurred despite the employment of a predator-control specialist.

Several factors probably accounted for the increase in sheep losses to coyotes. In the past, the Field Station was surrounded on
3 sides by ranchers who managed shecp. All of these producers ventually abandoned sheep production. This not only resulted in less effort in predator control but also probably concentrated predation on the Field Station sheep. Nielsen (1977) found that in 5 western states, more high-loss $(8 \%$ or more docked la mbs killed by predators) than low-loss (0-3\% of docked lambs killed by predators) sheep producers had no other producers within $16 \mathrm{~km}$. Lowloss producers consistently tended to operate in areas of relatively high concentration of sheep.

Generally, station personnel and ranchers in the area report that coyotes are more numerous than they were in the past. The increase in coyote numbers may be due in part to the ban on toxicants in 1972. Until that time, personnel at the Hopland Field Station set out horsemeat laced with strychnine for predator control.

Coyotes killed more sheep from October to March than from April to September (Fig. 1). Lambs were killed more often than ewes and most lambs were killed during the first 3 months of age. Beginning in July, predation on ewes was increasingly evident. This was due to at least 2 reasons. First, most lambs were sold in June and therefore fewer lambs were available to predators. Second, in October, lambs were classified as yearlings and animal deaths in this age grouped were included with adult sheep losses. Lambs killed in December were part of the following years lamb crop. Thus, when lambs were available, coyotes preyed more on them than on ewes, but after lambs were either sold or grew to maturity, coyote predation on adult sheep increased.

About $8 \%$ of the known predation losses was due to dogs (Table 1). Based on 3-year running averages, there was a statistically significant $(R=0.648)$ increase in the number of sheep killed by dogs since 1973. Dogs caught preying on sheep were usually shot. Few dogs in the area are feral; most had been abandoned or belonged to nearby residents. The increase in dog predation was probably related in part to an increase in the local human population and a lack of enforcement of dog-leash laws. A greater public awareness of the damage dogs can cause and stricter enforcement of county dog laws would probably reduce livestock losses to dogs.

Finally, $3 \%$ of the sheep losses to predators was due to black bear, mountain lion, and golden eagles (Table 1). While bear and lion are uncommon, eagles are regularly seen and periodically nest on the Field Station.

\section{Economic Losses}

Nesse et al. (1976), Gee et al. (1977), Taylor et al. (1978), and others have discussed the economic impact predation has on sheep

Table 2. Present value of sheep known to have been killed at the University of California Hopland Field Station, 1973-1983.

\begin{tabular}{lcccccr}
\hline \hline Year & $\begin{array}{c}\text { No. lambs } \\
\text { killed }\end{array}$ & $\begin{array}{c}\text { Price/ } \\
\text { lamb }(\$)\end{array}$ & $\begin{array}{c}\text { Present } \\
\text { value }(\$)^{\prime}\end{array}$ & $\begin{array}{c}\text { No. ewes } \\
\text { killed }\end{array}$ & $\begin{array}{c}\text { Price/ } \\
\text { ewe }(\$)\end{array}$ & $\begin{array}{c}\text { Present } \\
\text { value }(\$)^{\prime}\end{array}$ \\
\hline 1983 & 28 & 80 & 2,240 & 20 & 60 & 1,200 \\
1982 & 70 & 75 & 5,618 & 11 & 60 & 706 \\
1981 & 71 & 85 & 6,910 & 63 & 60 & 4,328 \\
1980 & 26 & 85 & 2,707 & 41 & 60 & 3,014 \\
1979 & 60 & 85 & 6,686 & 30 & 60 & 2,360 \\
1978 & 21 & 85 & 2,504 & 35 & 60 & 2,946 \\
1977 & 66 & 75 & 7,430 & 22 & 50 & 1,651 \\
1976 & 60 & 50 & 4,818 & 32 & 35 & 1,799 \\
1975 & 10 & 45 & 773 & 27 & 30 & 1,392 \\
1974 & 11 & 45 & 910 & 20 & 30 & 1,103 \\
1973 & 9 & 35 & 620 & 11 & 30 & 649 \\
Total & & & & & & 21,148 \\
value & & & 41,216 & & &
\end{tabular}

Present value $=($ No. killed $)($ Price $/$ animal $)(1.07)^{\mathrm{n}} ;$ where $(1.07)^{\mathrm{n}}=(1+7 \%$ interest rate per year)

enterprises. Scrivner and Conner (1984) identified factors often overlooked when estimating the cost of predation on livestock. At the Hopland Field Station, the most significant cost resulting from predation is the loss of income from animals which are killed.

The present value of livestock known to have been killed by 
predators from 1973 to 1983 was estimated to be $\$ 62,364$ (Table 2). The total present value of Field Station income (based on a $7 \%$ interest rate) from the sale of sheep and wool was $\$ 600,800$. Thus, the value of livestock killed by predators, amounted to $10 \%$ of the income received through the sale of sheep and sheep products. This estimate of the economic losses to predators is conservative since it does not include the value of missing animals which were killed by predators. Also, the value of sheep killed is based on their market value. Additionally, in this case, nearly all sheep were used in various research projects and when sheep were killed data were lost. Finally, economic estimates for ewe losses do not include the value of future lamb crop potential.

\section{Literature Cited}

Armentrout, D. 1980. Environmental viewpoint. p. 6-9. In: Proc. of the Predator Control Summit. Texas Dep. Agr., Austin, Texas.

Gee, C.K., R.S. Magleby, W.R. Bailey, R.L. Gum, and L.M. Arthur. 1977. Sheep and lamb losses to predators and other causes in the western United States. Nat. Resour. Econ. Div., Econ. Res. Serv., U.S. Dep. Agr., Agr. Econ. Rep. No. 369.
Gibbons, J.D. 1976. Nonparametric methods for quantitative analysis. Holt, Rinehart and Winston. New York, New York.

Murphy, A.H., and H.F. Heady. 1983. Vascular plants at the Hopland Field Station, Mendocino County, California. The Wasmann J. of Biol. 41:53-96.

Nesse, G.E., W.M. Longhurst, and W.E. Howard. 1976. Predation and sheep industry in California, 1972-1974. Univ. Calif. Div. Agr. Sci. Bull. 1878 .

Nielsen, D.B. 1977. High/low predation-some why factors. Utah Sci. 38:82-86.

Scrivner, J.H., and J.R. Conner. 1984. Costs and returns of Angora goat enterprises with and without coyote predation. J. Range Manage. 37:166-171.

Taylor, R.G., J.P. Workman, and J.E. Bowns. 1978. The economics of sheep predation in southwestern Utah. J. Range Manage. 32:317-321.

U.S. Fish and Wildlife Service. 1978. Predator damage in the west: a study of coyote management alternatives. U.S. Dep. Inter., Washington, D.C. 